\title{
Pelatihan Administrasi Digital Untuk Antisipasi Kegiatan Sekolah di Masa Pandemi Covid 19
}

\author{
Harry Witriyono \\ Universitas Muhammadiyah Bengkulu \\ e-mail: harrywitriyono@umb.ac.id \\ Sandhy Fernandez \\ Universitas Muhammadiyah Bengkulu \\ e-mail: sandhy_fernandez@gmail.com \\ Dori Mabrori \\ Universitas Muhammadiyah Bengkulu \\ e-mail: dorimabrori33@gmail.com
}

\begin{abstract}
Abstrak
Kegiatan sekolah di masa pandemi Covid 19 memaksa para guru dan para murid untuk melakukan kegiatan sekolah dalam bentuk pembelajaran di rumah. SD Negeri 05 Bengkulu Tengah menggunakan metode pembelajaran di rumah dengan mengharuskan para orang tua siswa ke sekolah untuk mengambil dan menyerahkan dokumen-dokumen pembelajaran anak-anaknya. Untuk mengantisipasi kegiatan administrasi sekolah yang penting ini maka diadakanlah pelatihan administrasi digital bagi sekolah sehingga kegiatan tersebut tetap berlangsung dengan baik walaupun dalam masa pandemi. Hasil pelatihan administrasi ini terciptanya website sekolah, video profil sekolah, pengetahuan akan manajemen laporan pendidikan K13 melalui aplikasi Microsoft Excel dan pemanfaatan beberapa aplikasi pembelajaran daring yang tersedia pada jaringan internet.
\end{abstract}

Kata Kunci : aplikasi, K13, pembelajaran, website, video

\begin{abstract}
School activities during the Covid-19 pandemic forced teachers and students to carry out school activities in the form of learning at home. SD Negeri 05 Bengkulu Tengah uses the home learning method by requiring parents to come to school to collect and submit their children's learning documents. To anticipate this important school administration activity, digital administration training was held for schools so that these activities continued well even during the pandemic. The results of this administrative training are the creation of a school website, school profile videos, knowledge of K13 education report management through the Microsoft Excel application and the use of several online learning applications available on the internet network.
\end{abstract}

Keywords : application, K13, learning, website, video

\section{Pendahuluan}

Penyebaran virus Covid-19 berdampak pada proses pembelajaran di sekolah. Hal ini juga terjadi pada kegiatan pembelajaran dan administrasi sekolah pada Sekolah Dasar Negeri 05 Bengkulu Tengah. Kegiatan pembelajaran dilakukan dengan bentuk pembelajaran di rumah yang melibatkan orang tua murid untuk mengambil dan menyerahkan dokumen pembelajaran anakanaknya di sekolah. 


\section{Harry Witriyono, Sandhy Fernandez, Dori Mabrori}

Pelatihan Administrasi Digital Untuk Antisipasi Kegiatan Sekolah di Masa Pandemi Covid 19

Kegiatan pembelajaran tidak dapat dilakukan sepenuhnya dalam bentuk daring dikarenakan kondisi jaringan internet yang masih belum tersebar merata di Kabupaten Bengkulu Tengah dan sekitarnya. Selain itu juga ketersediaan perangkat pembelajaran daring masih kurang bagi peserta didik dan orang tua murid, kecuali hanya menggunakan smartphone. Untuk mengatasi kesenjangan ini maka dibutuhkan peran serta juga dari guru kepada murid dalam mencari sumber informasi pembelajaran bagi peserta didiknya (Wekke and Hamid , 2013; Wildan et al, 2020).

Sekolah Dasar Negeri 05 Bengkulu Tengah juga belum mempunyai website sekolah yang berguna bagi promosi sekolah dan penyediaan informasi publik mengenai sekolah tersebut. Informasi website berdampak penting dalam promosi secara daring bagi suatu institusi (Wilson and Keni 2018). Dengan demikian penting bagi promosi dan tersedianya informasi publik mengenai sekolah tersebut.

Pelaksanaan pengabdian ini juga didasari keberhasilan penelitian penulis terdahulu dalam mengembangkan aplikasi pada jaringan internet. Pada penelitian tentang web service, penulis berhasil melakukan penelitian tentang penggunaan web service bagi kebutuhan inter koneksi informasi dan data dari server perpustakaan dan server sistem akademik Universitas Muhammadiyah Bengkulu (Prihantoro and Witriyono 2019). Hal inilah yang memberi motivasi besar bagi keberhasilan kegiatan pengabdian pada masyarakat ini.

\section{Metode}

Pelaksanaan pengabdian masyarakat ini berlangsung selama satu bulan dari tanggal 10 Nopember 2020 hingga 10 Desember 2020. Tempat pelaksanaan di Sekolah Dasar Negeri 05 Bengkulu Tengah, Kabupaten Bengkulu Tengah. Pelaksanaan melibatkan beberapa mahasiswa dalam program Perkuliahan Praktek Kerja Lapangan dari Fakultas Teknik, Universitas Muhammadiyah Bengkulu.

Sebelum melakukan proses pengabdian, tahapan awal adalah inventarisasi permasalahan pada institusi mitra dengan menggunakan metode wawancara dan observasi langsung selama beberapa hari. Hasil dari tahapan analisa dan inventarisasi permasalahan ini ditemukan permasalah pokok yang dapat diberikan solusinya dalam rentang waktu kegiatan tersebut adalah sebagai berikut.

- Kesulitan para guru dalam menyajikan laporan peserta didik pada Rapor K13 yang dibuat dengan menggunakan aplikasi Microsoft Excel.

- Kesulitan para guru dalam penyediaan informasi belajar daring bagi peserta didik dan orang tuanya dalam pendampingan pembelajaran di rumah. 
Harry Witriyono, Sandhy Fernandez, Dori Mabrori

Pelatihan Administrasi Digital Untuk Antisipasi Kegiatan Sekolah di Masa Pandemi Covid 19

- Belum tersedianya website untuk kepentingan promosi dan informasi sekolah kepada publik.

Selanjutnya dari hasil analisa dan inventarisasi permasalahan tadi, kami mencoba memberikan solusinya berupa beberapa kegiatan yang dilaksanakan secara terstruktur dan terjadwal seperti terlihat pada Tabel 1 .

Tabel 1. Daftar Pelaksanaan Kegiatan Pengabdian Pada Sekolah Dasar Negeri 05 Bengkulu Tengah

\begin{tabular}{|c|c|c|c|}
\hline No. & Tanggal & Uraian Kegiatan & Waktu Pengerjaan \\
\hline 1 & $10-11-2020$ & Penyerahan peserta PKL ke tempat PKL & 1 hari \\
\hline 2 & $11-11-2020$ & Diskusi mengenai kendala yang dihadapi atau ingin diselesaikan & 1 hari \\
\hline 3 & $12-11-2020$ & $\begin{array}{l}\text { Penyampaian materi untuk aplikasi classroom 1. Adapun materi } \\
\text { yang disampaikan meliputi: } \\
\text { 1. Cara pembuatan account classroom } \\
\text { 2. Cara login ke aplikasi classroom } \\
\text { 3. Diskusi dan tanya jawab }\end{array}$ & 3 jam pertemuan \\
\hline 4 & $17-11-2020$ & $\begin{array}{l}\text { Penyampaian materi untuk aplikasi classroom } 2 \text {. Adapun materi } \\
\text { yang disampaikan meliputi: } \\
\text { 1. Cara pembuatan kelas } \\
\text { 2. Diskusi dan tanya jawab }\end{array}$ & 3 jam pertemuan \\
\hline 5 & $18-11-2020$ & $\begin{array}{l}\text { Penyampaian materi untuk aplikasi classroom 3. Adapun materi } \\
\text { yang disampikan meliputi: } \\
\text { 1. Cara pembuatan absen } \\
\text { 2. Diskusi dan tanya jawab }\end{array}$ & 3 jam pertemuan \\
\hline 6 & $19-11-2020$ & $\begin{array}{l}\text { Penyampaian materi untuk aplikasi classroom 4. Adapun materi } \\
\text { yang disampikan meliputi: } \\
\text { 1. Cara upload tugas/ materi } \\
\text { 2. Diskusi dan tanya jawab }\end{array}$ & 3 jam pertemuan \\
\hline 7 & $24-11-2020$ & $\begin{array}{l}\text { Penyampaian materi untuk aplikasi classroom } 5 \text {. Adapun materi } \\
\text { yang disampikan meliputi: } \\
\text { 1. Cara input-output nilai } \\
\text { 2. Diskusi dan tanya jawab }\end{array}$ & 3 jam pertemuan \\
\hline 8 & $25-11-2020$ & $\begin{array}{l}\text { Penyampaian materi untuk aplikasi Microsoft Office Word } 1 . \\
\text { Adapun materi yang disampaikan meliputi: } \\
\text { 1. Pengenalan interface dan tools } \\
\text { 2. Diskusi dan tanya jawab }\end{array}$ & 3 jam pertemuan \\
\hline 9 & $26-11-2020$ & $\begin{array}{l}\text { Penyampaian materi untuk aplikasi Microsoft Office Word } 2 . \\
\text { Adapun materi yang disampaikan meliputi: } \\
\text { 1. Teknik penulisan yang digunakan pada aplikasi Microsoft } \\
\text { Office Word } \\
\text { 2. Diskusi dan tanya jawab }\end{array}$ & 3 jam pertemuan \\
\hline 10 & $01-12-2020$ & Penyampaian materi untuk aplikasi Microsoft Office Word 3. & 3 jam pertemuan \\
\hline
\end{tabular}


Harry Witriyono, Sandhy Fernandez, Dori Mabrori

Pelatihan Administrasi Digital Untuk Antisipasi Kegiatan Sekolah di Masa Pandemi Covid 19

\begin{tabular}{|c|c|c|c|}
\hline & & $\begin{array}{l}\text { Adapun materi yang disampaikan meliputi: } \\
\text { 1. Teknik merapikan tulisan agar sesuai dengan keinginan } \\
\text { penulis } \\
\text { 2. Diskusi dan tanya jawab }\end{array}$ & \\
\hline 11 & $02-12-2020$ & $\begin{array}{l}\text { Penyampaian materi untuk aplikasi Microsoft Office Excel } 1 . \\
\text { Adapun materi yang disampaikan meliputi: } \\
\text { 1. Pengenalan interface dan tools } \\
\text { 2. Diskusi dan tanya jawab }\end{array}$ & 3 jam pertemuan \\
\hline 12 & $03-12-2020$ & $\begin{array}{l}\text { Penyampaian materi untuk aplikasi Microsoft Office Excel } 2 . \\
\text { Adapun materi yang disampaikan meliputi: } \\
\text { 1. Bekerja dengan tabel } \\
\text { 2. Diskusi dan tanya jawab }\end{array}$ & 3 jam pertemuan \\
\hline 13 & 04-12-2020 & $\begin{array}{l}\text { Penyampaian materi untuk aplikasi Microsoft Office Excel } 3 . \\
\text { Adapun materi yang disampaikan meliputi: } \\
\text { 1. Pengolahan dan pengoperasian (manipulasi data) pada tabel } \\
\text { laporan peserta didik K13. } \\
\text { 2. Diskusi dan tanya jawab } \\
\end{array}$ & 3 jam pertemuan \\
\hline 14 & 04-12-2020 & $\begin{array}{l}\text { Penyampaian materi untuk aplikasi Microsoft Office Excel } 4 . \\
\text { Adapun materi yang disampaikan meliputi: } \\
\text { 1. Pengenalan rumus operasi pada aplikasi Microsoft Office } \\
\text { Excel pada laporan peserta didik K13 } \\
\text { 2. Diskusi dan tanya jawab }\end{array}$ & 3 jam pertemuan \\
\hline 15 & $05-12-2020$ & $\begin{array}{l}\text { Penyampaian materi untuk aplikasi Microsoft Office Excel } 5 . \\
\text { Adapun materi yang disampakan meliputi: } \\
\text { 1. Penerapan rumus operasi pada aplikasi Microsoft Office } \\
\text { Excel yang digunakan oleh guru (menggunakan contoh kasus } \\
\text { yang diberikan oleh guru) } \\
\text { 2. Diskusi dan tanya jawab }\end{array}$ & 3 jam pertemuan \\
\hline 16 & $20-11-2020$ & $\begin{array}{l}\text { Pengambilan footage dan B-Roll untuk pembuatan video profil } \\
\text { sekolah (termasuk penentuan tema, kata sambutan dan lainnya) }\end{array}$ & 3 hari \\
\hline 17 & $20-11-2020$ & $\begin{array}{l}\text { Melakukan proses edit dan pemasukan data footage serta B-Roll } \\
\text { (dikarenakan proses edit dilakukan dalam beberapa tahap), setelah } \\
\text { fix baru dilakukan rendering final }\end{array}$ & 7 hari \\
\hline 18 & $21-11-2020$ & $\begin{array}{l}\text { Melakukan analisa dan pengumpulan bahan untuk pembuatan } \\
\text { web sekolah, pendaftaran hosting dan domain pada } \\
\text { http://sdn05bengkulutengah.mysch.id/ }\end{array}$ & 3 hari \\
\hline 19 & 21-11-2020 & $\begin{array}{l}\text { Pengisian data sekolah pada website profil, meliputi: } \\
\text { 1. Kata pengantar Kepala sekolah } \\
\text { 2. Struktur sekolah } \\
\text { 3. Kegiatan extrakurikuler sekolah } \\
\text { 4. Kata sambutan kepala sekolah baik berupa video maupun } \\
\text { tulisan } \\
\text { 5. Visi dan Misi. } \\
\text { Setelah itu dilakukan pengaktifan web profil sekolah }\end{array}$ & 5 hari \\
\hline
\end{tabular}




\begin{tabular}{|l|l|l|c|}
\hline 20 & $11-12-2020$ & Penjemputan peserta PKL & 1 hari \\
\hline
\end{tabular}

\section{Hasil dan Pembahasan}

Pelaksanaan pengabdian masyarakat dari dosen dan mahasiswa pada Fakultas Teknik Universitas Muhammadiyah Bengkulu ini merupakan kegiatan rutin yang dilaksanakan pada semester genap dari tahun akademik berjalan. Sebelum dilaksanakan proses pengabdian dilakukan terlebih dahulu penjajakan lokasi mitra pengabdian dan penyampaian surat-surat mengenai kesediaan mitra dalam program pengabdian pada masyarakat ini.

Setelah mitra menyatakan kesediaan, maka dosen dan mahasiswa melakukan pra survey yang merupakan kegiatan awal untuk mendapatkan informasi awal dan kelayakan pelaksanaan kegiatan. Pelaksanaan dilakukan 3 hari sebelum jadwal resmi program pengabdian tersebut dilaksanakan, dan akhirnya diambil kesimpulan bahwa berdasarkan surat pernyataan mitra dan survey lapangan kegiatan pengabdian layak untuk dilaksanakan.

Secara kronologis hasil pelaksanaan pengabdian dilaksanakan sesuai jadwal yang telah dibuat dan telah didiskusikan dengan pihak mitra. Kegiatan pertama yang dilakukan pada proses pengabdian adalah inventarisasi dan analisa permasalahan pada mitra yang kemudian kami diskusikan untuk pelaksanaan penyelesaian masalahnya. Secara garis besar pelaksanaan kegiatan pengabdian seperti tampak pada Tabel 2.

Tabel 2. Garis Besar Kegiatan Pelaksanaan Pengabdian

\begin{tabular}{|c|c|c|c|}
\hline No. & Nama Kegiatan & Uraian Pelaksanaan dan Kebutuhan & Target Pelaksanaan \\
\hline 1 & Pelatihan LMS Google Classroom & 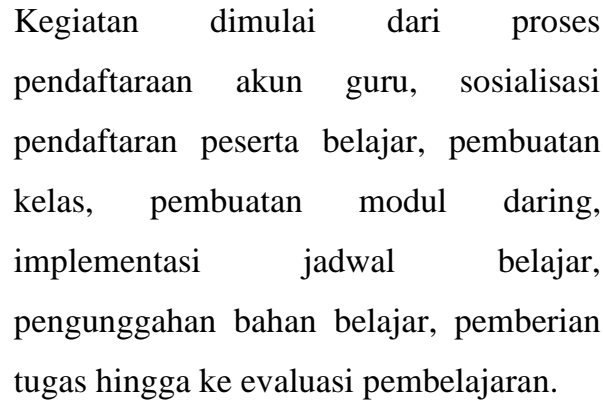 & Para guru dan siswa. \\
\hline 2. & $\begin{array}{l}\text { Pelatihan Aplikasi Microsoft Word } \\
\text { dan Microsoft Excel }\end{array}$ & $\begin{array}{l}\text { Penyempurnaan pemanfaatan aplikasi } \\
\text { Microsoft Word dan Microsoft Excel bagi } \\
\text { pelaksanaan kegiatan Adminstrasi Digital } \\
\text { di Sekolah Dasar Negeri } 05 \text { Bengkulu } \\
\text { Tengah, mulai dari pembuatan surat- } \\
\text { surat, laporan, dokumen belajar hingga ke }\end{array}$ & Guru-Guru \\
\hline
\end{tabular}


Harry Witriyono, Sandhy Fernandez, Dori Mabrori

Pelatihan Administrasi Digital Untuk Antisipasi Kegiatan Sekolah di Masa Pandemi Covid 19

\begin{tabular}{|c|c|c|c|}
\hline & & $\begin{array}{l}\text { pelaporan hasil belajar peserta didik atau } \\
\text { Rapor K13. }\end{array}$ & \\
\hline 3. & Pembuatan Website Sekolah & $\begin{array}{l}\text { Pengumpulan bahan-bahan kebutuhan } \\
\text { website berupa naskah profil, foto-foto, } \\
\text { dan data serta informasi lain yang } \\
\text { dibutuhkan. Penentuan hosting dan } \\
\text { domain serta proses unggah ke server dan } \\
\text { pelatihan petugas penanggung jawab } \\
\text { website profil sekolah. }\end{array}$ & $\begin{array}{l}\text { Guru atau Petugas } \\
\text { Administrasi penanggung } \\
\text { jawab website } \\
\text { sekolah }\end{array}$ \\
\hline 4. & Pembuatan Video Profil Sekolah & $\begin{array}{l}\text { Pengumpulan Bahan, Pembuatan Story } \\
\text { Board, Proses Editing, Proses Authoring, } \\
\text { Rendering dan Dokumentasi pada Media } \\
\text { Simpan DVD. }\end{array}$ & $\begin{array}{l}\text { Guru Bagian Prasarana dan } \\
\text { Semua Guru. }\end{array}$ \\
\hline
\end{tabular}

Hasil pelaksanaan kegiatan pertama dan kedua dan keempat terrekam dalam foto-foto kegiatan seperti tampak pada Gambar 1, Gambar 2, dan Gambar 3. Beberapa video dokumentasi dapat dilihat pada alamat https://youtu.be/b6IZySLtUmo.

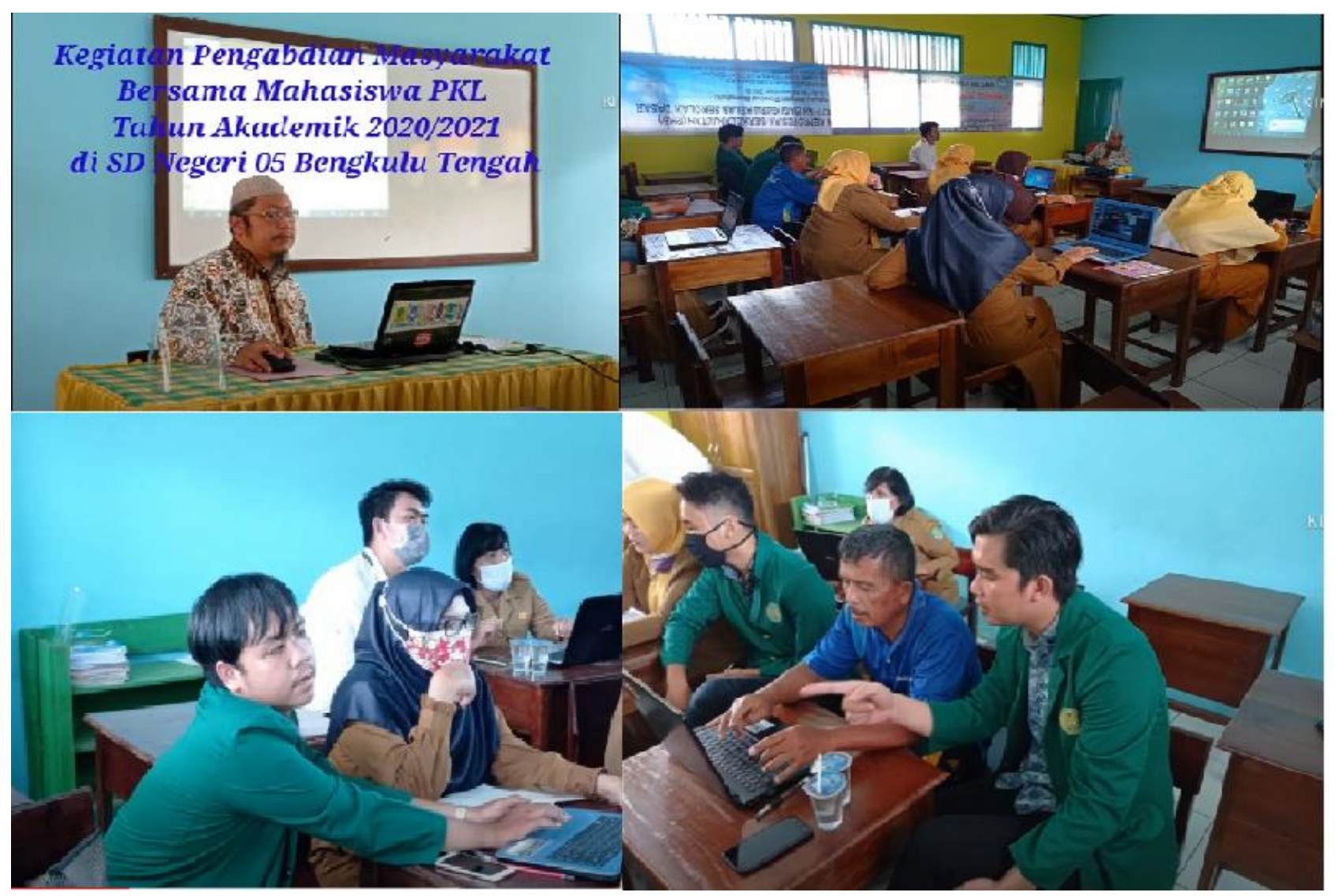

Gambar 1. Kegiatan Pelatihan Aplikasi Microsoft Word dan Excel bagi Kegiatan Administrasi Guru. 
Harry Witriyono, Sandhy Fernandez, Dori Mabrori

Pelatihan Administrasi Digital Untuk Antisipasi Kegiatan Sekolah di Masa Pandemi Covid 19

Pada Gambar 1 tampak kegiatan pengabdian berupa pelatihan penggunaan aplikasi Microsoft Word untuk pembuatan dokumen pembelajaran dan surat-surat administrasi sekolah serta artikel-artikel bagi kepentingan pelaporan para guru di sekolah. Untuk pelatihan aplikasi Microsoft Excel khusus dilakukan untuk kegiatan pada pelaporan hasil belajar peserta didik pada rapor model K13. Dari hasil pengabdian ini kami juga mendapatkan informasi pelaksanaan penelitian berikutnya dan proses kegiatan pengabadian berikutnya.

Selain itu untuk memberikan kelangsungan pembelajaran bagi para guru dan agar lebih menyebar lagi pada guru selain mitra pengabdian ini, pengabdi juga mengunggah video-video pembelanjaran dan pelatihan pada alamat Universal Resource Locator (URL) di https://youtu.be/JDH1RDix4AU, tampilan halaman videonya seperti tampak pada Gambar 2.

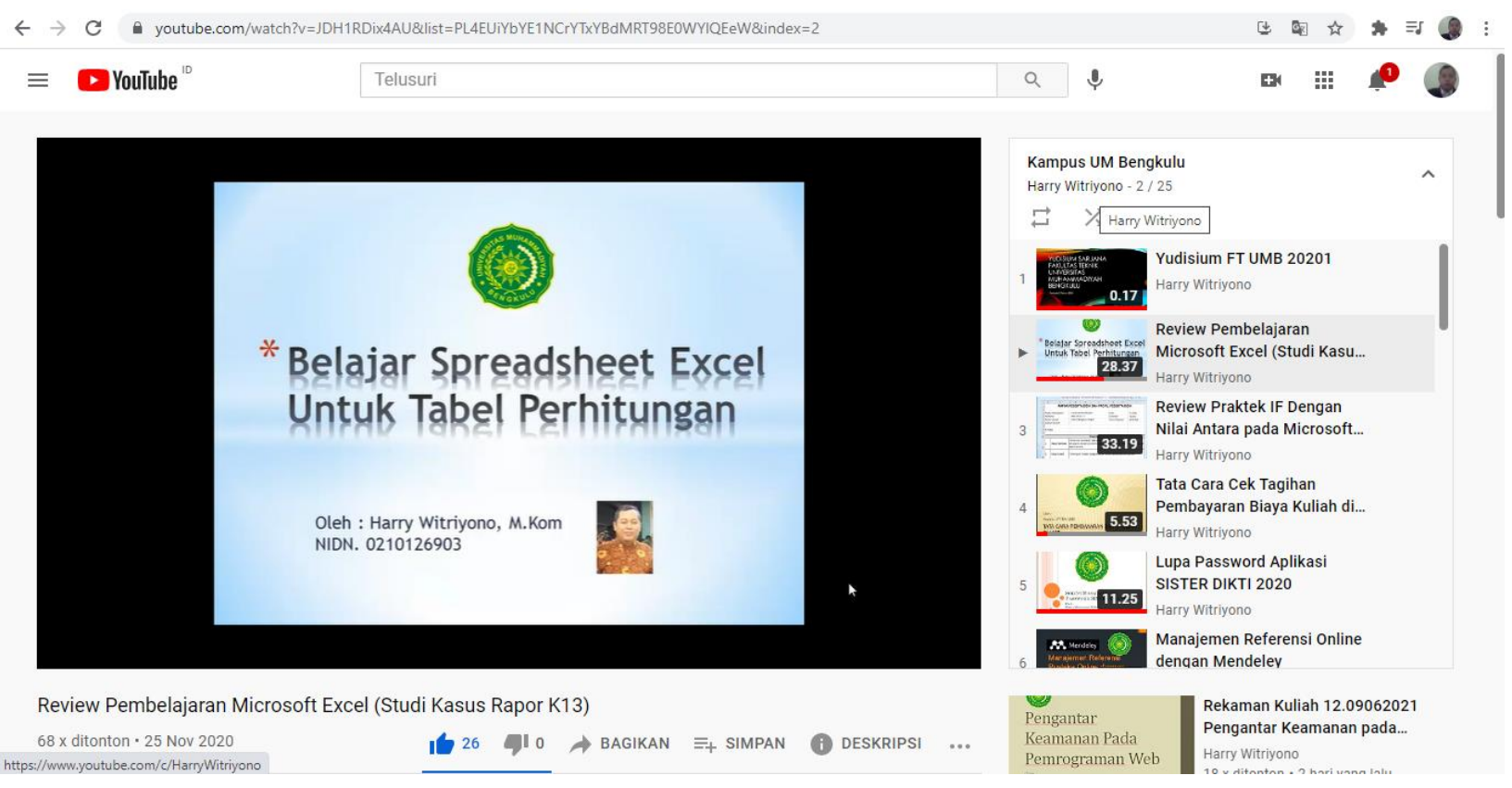

Gambar 2. Tampilan Halaman Video Pembelajaran Microsoft Excel Untuk Rapor K13. 
Harry Witriyono, Sandhy Fernandez, Dori Mabrori

Pelatihan Administrasi Digital Untuk Antisipasi Kegiatan Sekolah di Masa Pandemi Covid 19

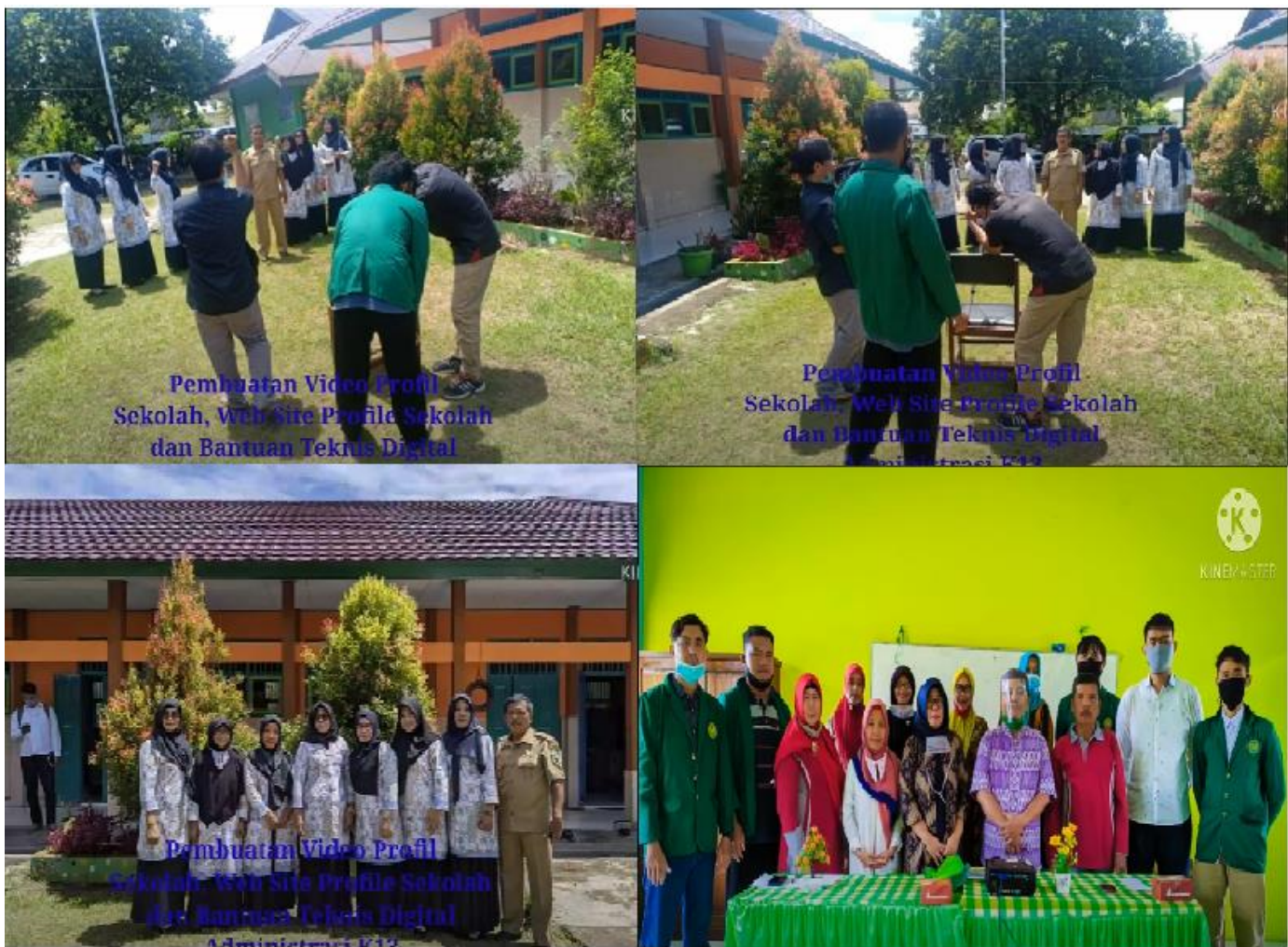

Gambar 3. Kegiatan Pengambilan Frame Video Profil Sekolah dan Closing Frame Video Profil.

Untuk kegiatan pembuatan website sekolah, kami memutuskan untuk memanfaatkan hosting, domain dan template yang hasilnya dapat diakses daring pada alamat URL http://sdn05bengkulutengah.mysch.id. Gambar tampilan muka website tersebut adalah seperti Gambar 4.

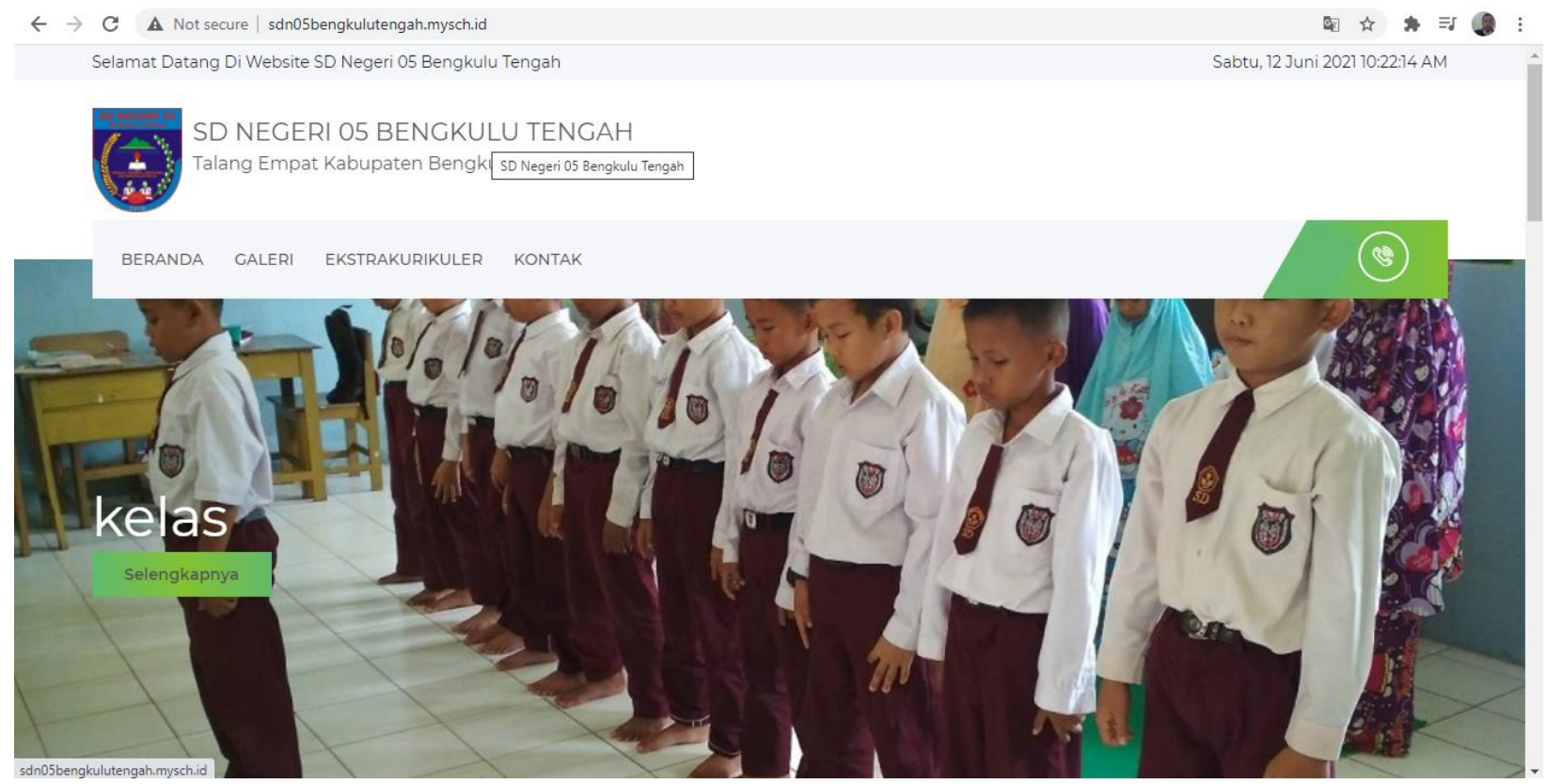

Gambar 4. Gambar Halaman Muka Website Profil Sekolah Dasar Negeri 05 Bengkulu Tengah. 


\section{Kesimpulan}

Pelaksanaan kegiatan pengabdian masyarakat dari dosen dan mahasiswa Fakultas Teknik Universitas Muhammadiyah Bengkulu dengan mitra Sekolah Dasar Negeri 05 Bengkulu Tengah, dengan tema Pelatihan Administrasi Digital Untuk Antisipasi Kegiatan Sekolah di Masa Pandemi Covid 19 ini berhasil dengan baik dan bermanfaat bagi mitra dapat dilanjutkan dengan beberapa kegiatan penelitian dan pengabdian berikutnya.

\section{Penghargaan/Ucapan terima kasih}

Ucapan terima kasih disampaikan pada Dekan Fakultas Teknik Universitas Muhammadiyah Bengkulu yang telah memberikan ijin sehingga terlaksananya kegiatan pengabdian pada masyarakat ini. Selain itu juga tersampaikan khusus pada semua Bapak/Ibu Guru dan Murid-Murid pada Sekolah Dasar Negeri 05 Bengkulu Tengah yang telah bersedia bekerja sama dalam kegiatan pengabdian dosen dan mahasiswa Fakultas Teknik Universitas Muhammadiyah Bengkulu.

\section{Daftar Pustaka}

Nugraha, W., Amalia, D., Soleh, A. M., Masitoh, F., \& Abdullah, A. (2020). Pelatihan Safety Management System bagi Pegawai Unit Penyelenggara Bandar Udara Gusti Syamsir Alam Kotabaru. Darmabakti: Jurnal Inovasi Pengabdian Dalam Penerbangan, 1(1), 19-29. https://doi.org/10.52989/darmabakti.v1i1.9

Prihantoro, Cahyo, and Harry Witriyono. 2019. "Perancangan Client Server Three Tier Pada Pembangunan Web Service Anggota Perpustakaan Universitas Muhammadiyah Bengkulu." Journal of Technopreneurship and Information System (JTIS). doi: 10.36085/jtis.v2i2.355.

Wekke, Ismail Suardi, and Sanusi Hamid. 2013. "Technology on Language Teaching and Learning: A Research on Indonesian Pesantren." Procedia - Social and Behavioral Sciences 83:585-89. doi: 10.1016/j.sbspro.2013.06.111.

Wilson, Nicholas, and Keni Keni. 2018. "Pengaruh Website Design Quality Dan Kualitas Jasa Terhadap Repurchase Intention: Variabel Trust Sebagai Variabel Mediasi.” Jurnal Manajemen Dan Pemasaran Jasa 11(2):291. doi: 10.25105/jmpj.v11i2.3006. 